\title{
Measurement of $\mathrm{CF}_{2} \mathrm{Cl}_{2}$ at Memanbetsu over the Period between October 1980 and March 1983
}

\author{
Michio Hirota and Hisafumi Muramatsu \\ Meteorological Research Institute, Tsukuba, Japan \\ Fumio Fukui, Fujio Muromatsu, Masahiko Hashimoto, \\ Masayuki Kuwashima, and Toshiharu Koike \\ Memanbetsu Magnetic Observatory, Memanbetsu, Japan
}

(Received Feb. 2, 1984 ; Revised May 18, 1984)

\begin{abstract}
In order to obtain the atmospheric lifetime of $\mathrm{CF}_{2} \mathrm{Cl}_{2}(\tau)$, the measurements of $\mathrm{CF}_{2} \mathrm{Cl}_{2}$ were performed from October 1980 to March 1983 at Memanbetsu, Hokkaido.

The trend of monthly mean volume mixing ratios of $\mathrm{CF}_{2} \mathrm{Cl}_{2}$ when the wind directions were between NW and $\mathrm{N}$ was considered to represent the trend of the background mixing ratios. In this case, the mean increase rate from October 1980 to March 1983 was $1_{5} \mathrm{ppt} /$ year $\left(\mathrm{ppt}=10^{-12}\right)$.

From the increase rate obtained in this study and the release rate reported by the Chemical Manufacturers Association (1983), $\tau$ was calculated to be $24(5 \sim \infty)$ years. Such a short lifetime seems to be due to the overestimation of the release rate in 1980 and 1981.
\end{abstract}

\section{Introduction}

Chlorofluorocarbons $\left(\mathrm{CF}_{2} \mathrm{Cl}_{2}\right.$ and $\left.\mathrm{CFCl}_{3}\right)$ are being accumulated in the atmosphere. The lifetimes of these compounds against the photodissociation in the stratosphere are considered about 110 years for $\mathrm{CF}_{2} \mathrm{Cl}_{2}$ and 70 years for $\mathrm{CFCl}_{3}$ (NAS, 1979). The persistent effect on the stratospheric ozone is based on their long lifetimes in the atmosphere.

No important tropospheric sinks have been identified for $\mathrm{CF}_{2} \mathrm{Cl}_{2}$ and $\mathrm{CFCl}_{3}$, though 10 $\sim 20$ years lifetimes for them could not be ruled out from the early measurements (Sze and $\mathrm{Wu}, 1976)$. Ausloos et al. (1977) only suggested that the photodecomposition on silica surface would be a possible sink for $\mathrm{CF}_{2} \mathrm{Cl}_{2}$ and $\mathrm{CFCl}_{3}$.

If there are other significant sinks for
$\mathrm{CF}_{2} \mathrm{Cl}_{2}$ and $\mathrm{CFCl}_{3}$, the lifetimes of these compounds will become much shorter and the effect on the stratospheric ozone will be much diminished. In 1978, Cunnold et al. (1978) proposed that the existence of unknown sinks can be checked through the analysis of long-term trends of the atmospheric burdens of $\mathrm{CF}_{2} \mathrm{Cl}_{2}$ and $\mathrm{CFCl}_{3}$.

In order to obtain the lifetime of $\mathrm{CF}_{2} \mathrm{Cl}_{2}$, the gas-chromatographic measurement of $\mathrm{CF}_{2} \mathrm{Cl}_{2}$ was started in October 1980 at $\mathrm{Me}$ manbetsu, Hokkaido.

\section{Method}

The rate of change of the atmospheric burden of $\mathrm{CF}_{2} \mathrm{Cl}_{2}$ in either hemisphere can be given by (1) and (2) by assuming a twobox model (Chang and Penner, 1978).

$$
\frac{d C_{N}}{d t}=S_{N}-\frac{1}{\tau_{N}} C_{N}-\frac{1}{\tau_{\mathrm{m}}}\left(C_{N}-C_{S}\right)
$$




$$
\frac{d C_{S}}{d t}=S_{S}-\frac{1}{\tau_{S}} C_{S}+\frac{1}{\tau_{\mathrm{m}}}\left(C_{N}-C_{S}\right)
$$

where:

$\mathrm{C}_{N}$ and $\mathrm{C}_{S}$ are the hemispheric burdens of $\mathrm{CF}_{2} \mathrm{Cl}_{2}$ at time $\mathrm{t}(\mathrm{N}$; north, $\mathrm{S}$; south). $\mathrm{S}_{N}$ and $\mathrm{S}_{S}$ are the hemispheric release rates.

$\tau_{N}$ and $\tau_{S}$ are the hemispheric lifetimes. $\tau_{\mathrm{m}}$ is the interhemispheric mixing time $(=\sim 1$ year $)$.

Assuming $\tau_{N}=\tau_{\mathrm{S}}=\tau$, and $\tau_{\mathrm{m}}=1$ year,

$$
\begin{aligned}
& C_{N}+C_{S}=\int_{0}^{t}\left(S_{N}\left(t^{\prime}\right)+S_{S}\left(t^{\prime}\right)\right) e^{(t /-t) / \tau} d t^{\prime} \\
& C_{N}-C_{S}=\int_{0}^{t}\left(S_{N}\left(t^{\prime}\right)-S_{S}\left(t^{\prime}\right)\right) e^{(t /-t)(1 / \tau+2 / \tau m)} d t^{\prime}
\end{aligned}
$$

$C_{N}\left(C_{S}\right)$ can be calculated from the data of $S_{N}\left(S_{S}\right)$ since the 1930's and the $\tau$. If actual $C_{N}\left(C_{S}\right)$ can be estimated from the observation, $\tau$ can be obtained from $C_{N}\left(C_{S}\right)$ and $S_{N}\left(S_{S}\right)$.

It is difficult to obtain the absolute value of $C_{N}\left(C_{S}\right)$ from observations of the $\mathrm{CF}_{2} \mathrm{Cl}_{2}$ mixing ratio, $X$, because the accuracy of $C_{N}\left(C_{S}\right)$ is strongly dependent on systematic errors in the measurement, and also because background mixing ratios are not neccessarily uniform in the atmosphere, i.e., the mean tropospheric mixing ratio, for example, is a little lower than that of the surface air (Rasmussen and Khalil, 1981).

The second method uses the time trend. The relative change of mixing ratios, $1 / \mathrm{X}$. $\mathrm{dX} / \mathrm{dt}$, observed at a single station is compared with that of $C_{N}\left(C_{S}\right)$, i. e., $1 / C_{N} \cdot \frac{d C_{N}}{d t}$, calculated from (3) and (4). In this cace, accuracy of measurement is relatively unimportant. The trend in $1 / \mathrm{X} \cdot \mathrm{dX} / \mathrm{dt}$ at a single station will not be much different from the trend of the hemispheric burden, $C_{N}\left(C_{S}\right)$, if the station is far away from the sources of the atmospheric $\mathrm{CF}_{2} \mathrm{Cl}_{2}$.

Gas-chromatographic measurement of $\mathrm{CF}_{2} \mathrm{Cl}_{2}$ was started in October 1980 at Memanbetsu, which is located on the coast of Lake Abashiri close to the Sea of Okhotsk in northeastern Hokkaido. The location of Memanbetsu is shown in Fig. 1. In Hokkaido, background mixing ratios had been frequentlyobserved by Makide et al. (1981).

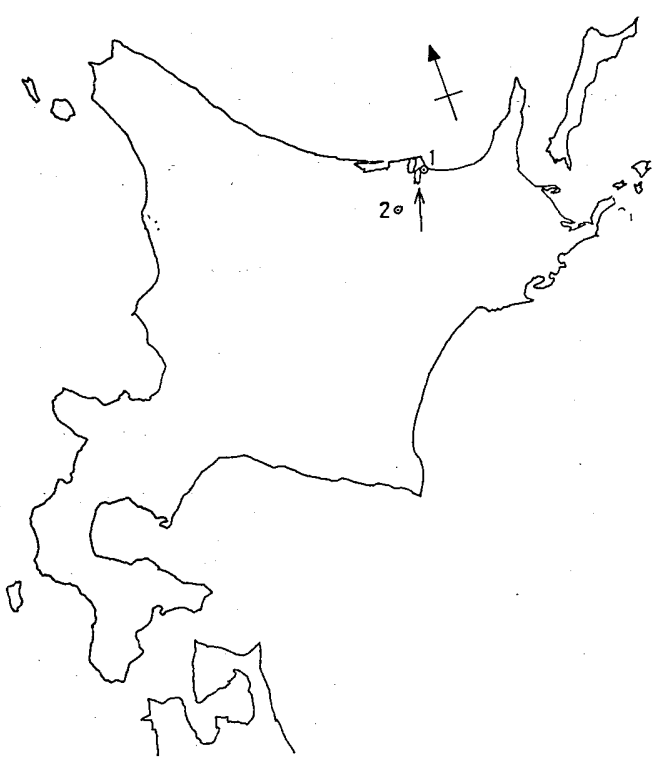

Fig. 1 Location of Memanbetsu $\uparrow$ : Memanbetsu. 1: Abashiri. 2: Kitami.

\section{Experimental}

An air sampler (Tokyo Electron) and a Perkin-Elmer Gas Chromatograph Sigma 1Sigma 10 system were set up at the $\mathrm{Me}$ manbetsu Magnetic Observatory, which is situated in the eastern suburbs of Memanbetsu.

Air $2.5 \mathrm{~m}$ above the ground surface was sampled through a copper tube $\left(1 / 8^{\prime \prime}\right.$ o. d. $)$ by means of an air pump into a $2 \mathrm{ml}$ gas sampling tube, and was then transferred into a stainless steel column ( $6 \mathrm{ft} \times 1 / 8^{\prime \prime}$ o. d.) filled with Porasil B $(80 \sim 100$ mesh $)$. An electron capture detector (ECD, ${ }^{63} \mathrm{Ni} 15 \mathrm{mCi}$ ) was used at $300^{\circ} \mathrm{C}$. A $95 \% \mathrm{Ar}^{-} 5 \% \mathrm{CH}_{4}$ mixture was used as the carrier gas at a flow rate of $25 \mathrm{ml} / \mathrm{min}$. The reference air, which was filled into a 50-1 stainless steel container up to the pressure of $7 \mathrm{~kg} / \mathrm{cm}^{2}$ by an oil-free compressor and which could be used for 40 $\sim 50$ days, was first analyzed. Then, after an hour, the outdoor air was sampled and analyzed. This pair of measurements was repeated every 6hrs. The mixing ratio of $\mathrm{CF}_{2} \mathrm{Cl}_{2}$ in the reference air was determined at the Meteorological Research Institute by a previously reported method (Hirota et al., 


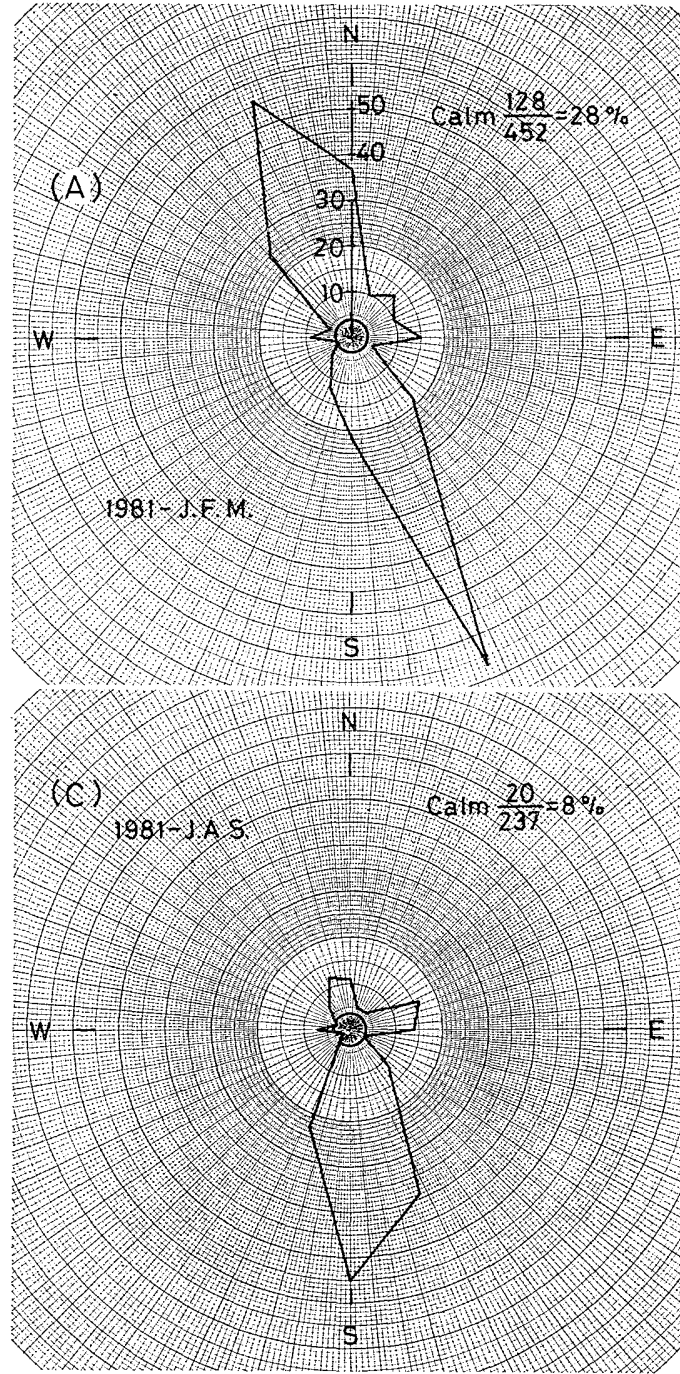

Fig. 2 Wind roses at Memanbetsu in 1981 (A): Jan.-Mar. (B): Apr.-Jun.

1982).

The variation coefficient in the repeated measurements of the reference air was about $4 \%$, and the detection limit was about $2_{5} \mathrm{ppt}$ $\left(=10^{-12}\right)$. The total precision in the measurements was estimated to be about $\pm 7 \%$.

The measurements were often interrupted by troubles in the controlling system. From May to September 1982, measurements were stopped owing to trouble in the timer which controlled the gas sampler.

When the outdoor air was sampled, wind direction and wind velocity were also mea-

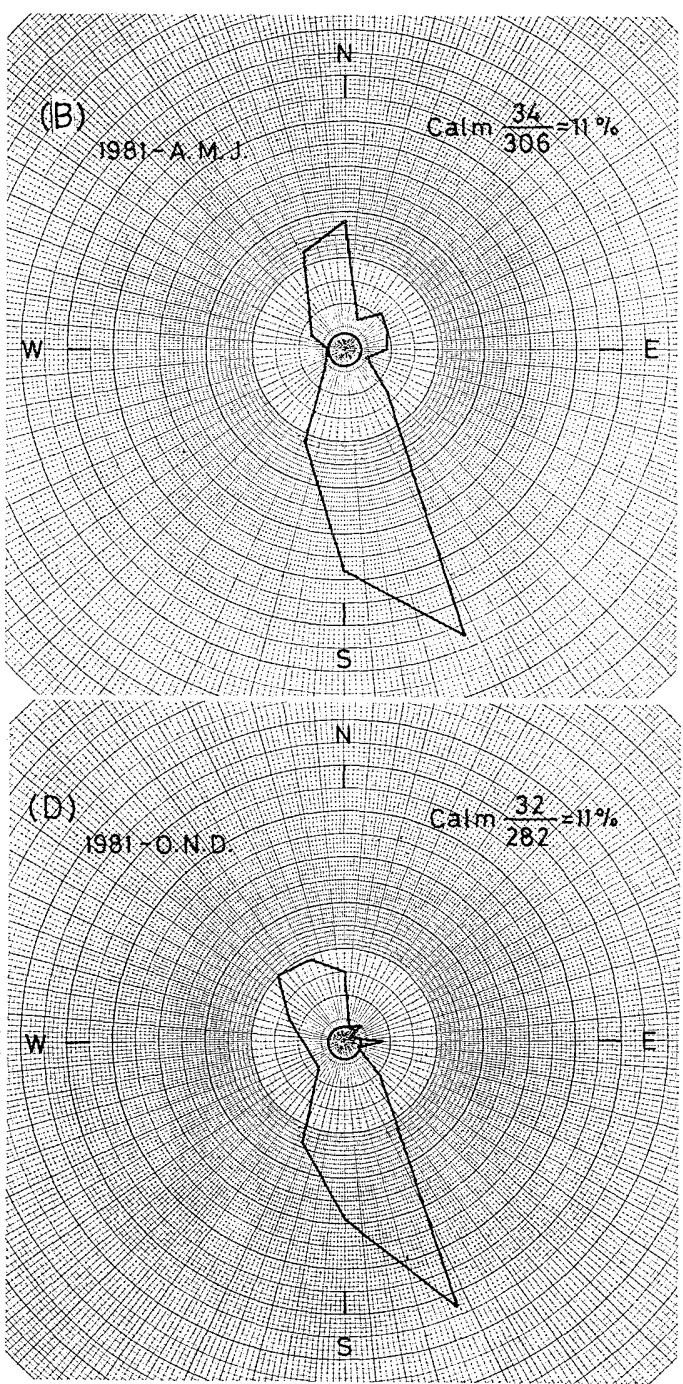

(C): Jul. -Sep. (D): Oct.-Dec.

sured.

\section{Results and Discussion}

Wind roses for every three months of 1981 are shown in Fig. 2. Through the year, winds from SSE and $S$ were predominant, and winds between NW and $\mathrm{N}$ were also predominant from January to March. Nearly the same trends were observed in other years. Therefore, the effect of polluted air from Abashiri City or Kitami City was considered to be small(see Fig. 1). Frequency histograms for volume mixing ratios for every three 


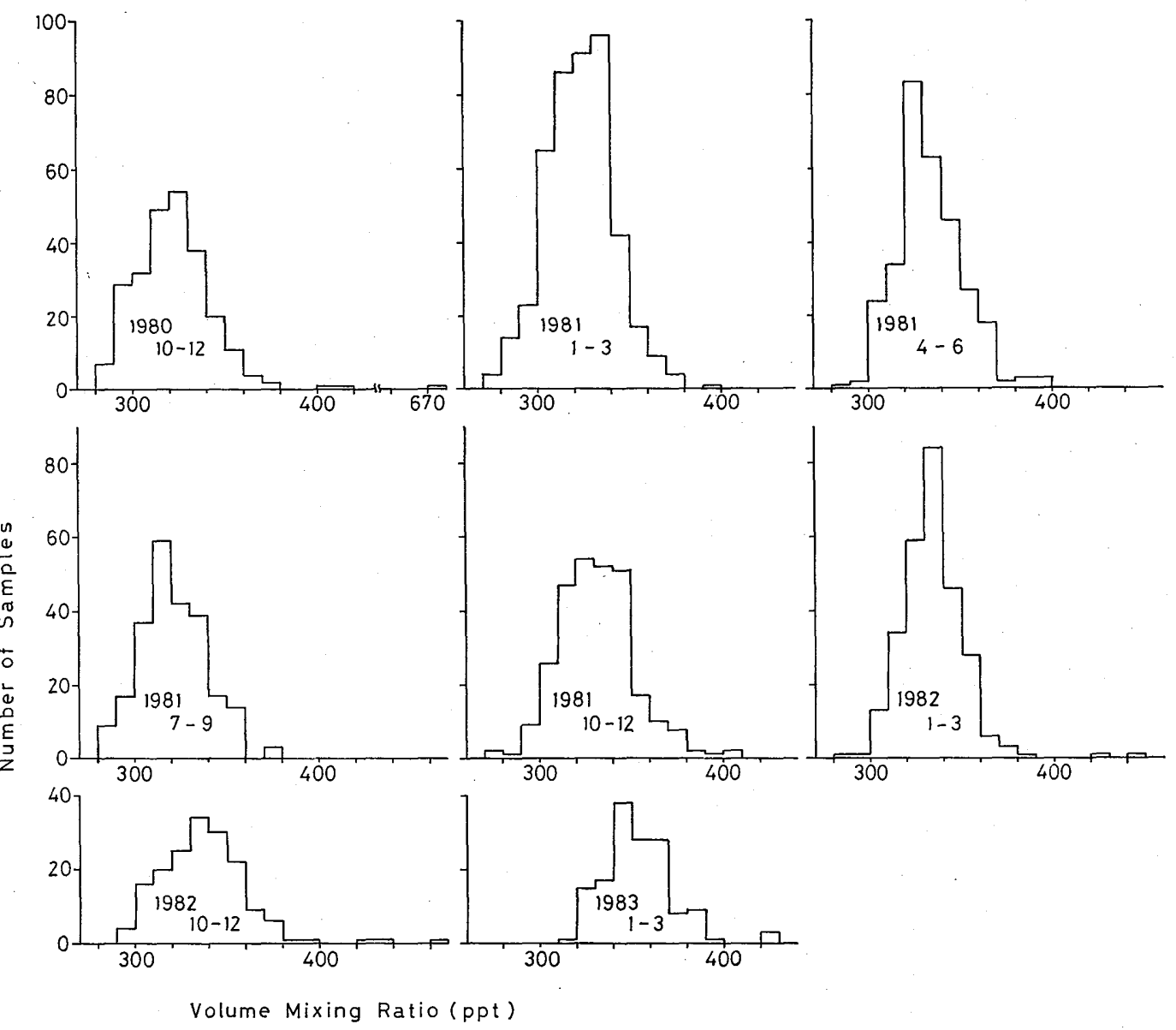

Fig. 3 Frequency histograms for volume mixing ratios of $\mathrm{CF}_{2} \mathrm{CI}_{2}$ at Memanbetsu between Oct.

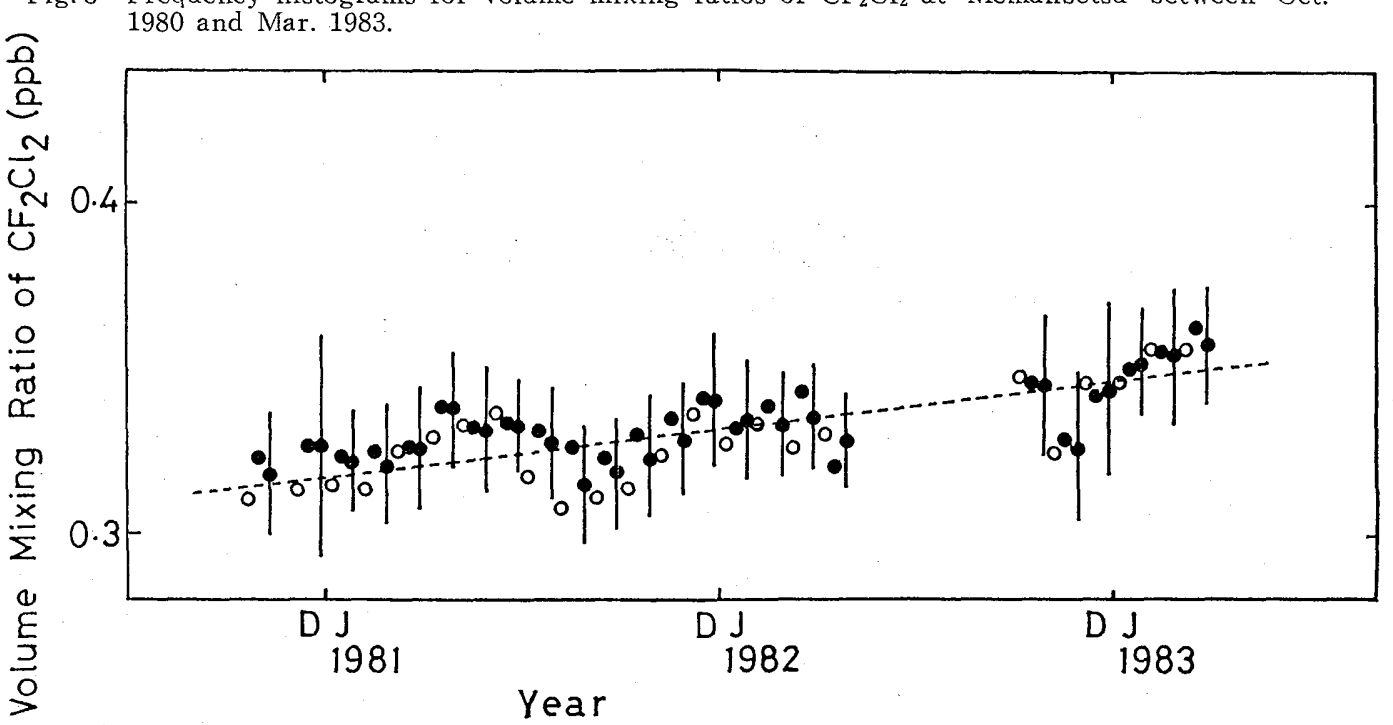

Fig. 4 Monthly mean volume mixing ratios of $\mathrm{CF}_{2} \mathrm{CI}_{2}$ at Memanbetsu : mean and $\mathrm{SD}$. : : mean when the wind directions were $\mathrm{SSE}$ and $\mathrm{S}$. o and ---: mean when the wind directions were between NW and $\mathrm{N}$, and their linear trend calculated by the method of least squares. 
Table 1. Monthly mean volume mixing ratios of atmospheric $\mathrm{CF}_{2} \mathrm{CI}_{2}$ at Memanbetsu (ppt)

\begin{tabular}{|c|c|c|c|c|c|c|c|}
\hline month & & $\begin{array}{l}\text { se } 1 \\
\mathrm{~m}\end{array}$ & $\mathrm{SD}$ & \multicolumn{2}{|c|}{$\begin{array}{c}\text { Case } 2^{2)} \\
\mathrm{n} \quad \mathrm{m}\end{array}$} & \multicolumn{2}{|c|}{$\begin{array}{c}\text { Case } 3^{3)} \\
\mathrm{n} \mathrm{m}\end{array}$} \\
\hline $\begin{array}{r}\text { Oct. }+ \text { Nov. } \\
1980\end{array}$ & 84 & $31_{8}$ & $1_{9}$ & 23 & $32_{3}$ & 10 & $31_{0}$ \\
\hline Dec. 1980 & 165 & $32_{7}$ & $3_{4}$ & 33 & $32_{7}$ & 39 & $31_{4}$ \\
\hline Jan. 1981 & 150 & $32_{2}$ & $1_{6}$ & 40 & $32_{3}$ & 39 & $31_{5}$ \\
\hline Feb. & 132 & $32_{1}$ & $1_{8}$ & 25 & $32_{5}$ & 24 & $31_{4}$ \\
\hline Mar. & 170 & $32_{6}$ & $1_{9}$ & 34 & $32_{6}$ & 55 & $32_{5}$ \\
\hline Apr. & 172 & $33_{8}$ & $1_{8}$ & 45 & 33 & 40 & $33_{0}$ \\
\hline May. & 92 & $33_{2}$ & $1_{9}$ & 44 & $33_{2}$ & 18 & $33_{4}$ \\
\hline Jun. & 42 & $33_{3}$ & $1_{4}$ & 26 & $33_{4}$ & 4 & $33_{7}$ \\
\hline Jul. & 79 & $32_{8}$ & $1_{7}$ & 36 & $33_{1}$ & 10 & $31_{7}$ \\
\hline Aug. & 40 & $31_{5}$ & $1_{8}$ & 9 & $32_{6}$ & 10 & $30_{8}$ \\
\hline Sep. & 118 & $31_{9}$ & $1_{7}$ & 49 & $32_{3}$ & 10 & $31_{2}$ \\
\hline Oct. & 104 & $32_{4}$ & $1_{9}$ & 40 & $33_{0}$ & 19 & $31_{4}$ \\
\hline Nov. & 66 & $32_{9}$ & $1_{7}$ & 21 & $33_{5}$ & 17 & $32_{4}$ \\
\hline Dec. & 112 & $34_{1}$ & $2_{0}$ & 41 & $34_{1}$ & 18 & $33_{7}$ \\
\hline Jan. 1982 & 122 & $33_{5}$ & $1_{8}$ & 32 & $33_{2}$ & 23 & $32_{8}$ \\
\hline Feb. & 109 & $33_{4}$ & $1_{6}$ & 18 & $33_{9}$ & 12 & $33_{3}$ \\
\hline Mar. & 47 & $33_{6}$ & $1_{5}$ & 8 & $34_{4}$ & 11 & $32_{6}$ \\
\hline Apr. & 34 & $32_{9}$ & $1_{5}$ & 12 & $32_{1}$ & 9 & $33_{2}$ \\
\hline Oct. $\quad 1982$ & 33 & $34_{6}$ & $22_{1}$ & 7 & $34_{5}$ & 5 & $34_{8}$ \\
\hline Nov. & 67 & $32_{7}$ & 2, & 16 & 329 & 21 & $32_{5}$ \\
\hline Dec. $\quad "$ & 71 & $34_{5}$ & $2_{6}$ & 25 & $34_{2}$ & 8 & $34_{6}$ \\
\hline Jan. 1983 & 113 & $35_{3}$ & $1_{6}$ & 32 & $35_{1}$ & 14 & $34_{7}$ \\
\hline Feb. $\quad \prime$ & 29 & $35_{5}$ & 21 & 4 & $35_{6}$ & 5 & $35_{6}$ \\
\hline Mar. & 4 & $35_{8}$ & $1_{8}$ & 1 & $36_{3}$ & 3 & $35_{6}$ \\
\hline
\end{tabular}

1) all samples

2) samples when the wind direction was SSE or $\mathrm{S}$

3) samples when the wind direction was $\mathrm{NW}$, NNW or N

$\mathrm{n}$ : number of samples. m: mean.

SD: standard deviation

months are shown in Fig. 3. The patterns of these histograms are roughly symmetrical, and this also indicates that the effect of local air pollution was small. If the effect of local air pollution is rather large, the envelope is very extended toward the side of higher mixing ratios (Penkett et al., 1979). When high mixing ratios of $\mathrm{CF}_{2} \mathrm{Cl}_{2}$ were observed, those of other halocarbons were mostly high. The measurement results of other halocarbons will be given elsewhere.

The lowest mixing ratios were often
Table 2. Calculated annual increase rates of the northern hemispheric $\mathrm{CF}_{2} \mathrm{CI}_{2}$

\begin{tabular}{|c|c|c|c|}
\hline & Case 1 & Case 2 & Case 3 \\
\hline $\begin{array}{c}\text { Wind direction } \\
\text { Annual increase } \\
\text { rate (ppt/year) }\end{array}$ & all & SSE, S & $\mathrm{NW}, \mathrm{NNW}, \mathrm{N}$ \\
$\begin{array}{c}\text { Mean mixing } \\
\text { ratio on Jan. } \\
1981 \text { (ppt) }\end{array}$ & 325.1 & 326.6 & 14.7 \\
\hline
\end{tabular}

observed when the wind directions were between NW and N, especially when the winds from the Sea of Okhotsk were lasting, i.e., the winter monsoon was prevailing. Therefore, we considered that the trend of monthly mean mixing ratios when the wind directions were between NW and N represented the trend of background mixing ratios.

Monthly mean mixing ratios and their standard deviations (SD) are shown in Table 1 (Case 1) and Fig. 4. Mean values range from $31_{5} \mathrm{ppt}$ to $35_{5} \mathrm{ppt}$, and the $\mathrm{SDs}$ are about $2_{0} \mathrm{ppt}$, which is roughly equal to the precision of the measurement. Monthly mean mixing ratios when the wind directions were SSE and S (Case 2) and between NW and $\mathrm{N}$ (Case 3) are also shown in Table 1 and Fig. 4. From monthly mean mixing ratios, increase rates for three cases were calculated by the method of least squares. In these calculations, $\mathrm{n} / \Sigma \mathrm{n}$ were used as weighting factors. The results are shown in Table 2 . The increase rate in Case 3 was $4.6 \% /$ year in January 1981. The variance of the residuals of the monthly mean values to the linear trend was 9 ppt in Case 3. Including this value, the increase rate in Case 3 ranged from $2.2 \% /$ year to $7.1 \% /$ year in January 1981.

Tominaga and Makide (1983) reported that the increase rate of the background mixing ratios of $\mathrm{CF}_{2} \mathrm{Cl}_{2}$ in Hokkaido was about 15 $\mathrm{ppt} /$ year for the last few years, which was in agreement with our value in Case 3. This also shows that the trend in Case 3 is considered to be the trend of the background mixing ratios.

The lifetime of $\mathrm{CF}_{2} \mathrm{Cl}_{2}$ was estimated using the increase rate for Case 3 and the atmospheric release rate of $\mathrm{CF}_{2} \mathrm{Cl}_{2}$ since 


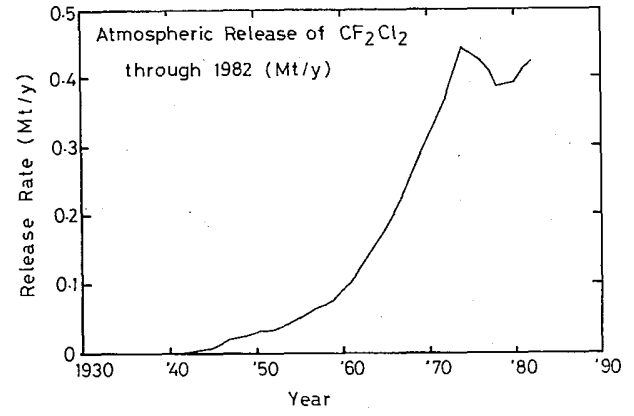

Fig. 5 Atmospheric release rate of $\mathrm{CF}_{2} \mathrm{Cl}_{2}$ (CMA, 1983) The annual release rate has a maximum in 1974. After, $u$ ul. 1971 , its fraction in the southern hemisphere was assumed to be $7 \%$ for the total release rate.

1931 (Fig. 5, Chemical Manufacturers Association (CMA), 1983, which is the same data as used by Cunnold et al., 1983). The northern hemispheric burdens of $\mathrm{CF}_{2} \mathrm{Cl}_{2}$ were calculated for various lifetime values. The increase rate of $4.6(2.2 \sim 7.1) \% /$ year for the northern hemispheric burden of $\mathrm{CF}_{2} \mathrm{Cl}_{2}$ in 1980 corresponded to the lif $\in$ time of 24 $(5 \sim \infty)$ years. Considering the rather large experimental errors, this value was not necessarily unreasonable. However, this value (24 years) was too small to explain the high increase rate $(>6 \%)$ up to 1979 (Cunnold et al., 1983). Cunnold et al. (1983) reported a lifetime of 769 years (lower limit of 81 years) using the Atmospheric Lifetime Experiment (ALE) data from July 1978 to June 1981. However, a lifetime of 13 years could be calculated from the data of the third year (Table 6 in Cunnold et al., 1983). They concluded that the trend analysis of the ALE data gave results that were reasonably consistent with the release data of CMA (1983), and suggested that the release rates in 1980 and 1981 would be overestimated by CMA (1983). Thus, a short lifetime of 24 years obtained in this study would be due to the overestimated release rates after 1980 rather than the underestimated release rates before 1979. If the lifetime is 81 years, the increase rate of $4.6 \% /$ year in January 1981 corresponds to the $7 \sim 8 \%$ reduction of the release rate in 1981.
In the model calculation, the trend was not so sensitive to the interhemispheric mixing time $\left(\tau_{\mathrm{m}}\right)$. When $\tau_{\mathrm{m}}$ was changed from 1 year to 2 years with fixed lifetimes $(\tau=5$, 24 and 1000 years), the increase rates on 1980 was changed by only $0.1 \%$, i. e., for example, $4.5 \% /$ year instead of $4.6 \%$ /year for the lifetime of 24 years. The ratio between two hemispheric burdens was sensitive to $\tau_{m}$.

\section{Conclusion}

In order to obtain the atmospheric lifetime of $\mathrm{CF}_{2} \mathrm{Cl}_{2}(\tau)$, trend analysis was applied to the gas-chromatographic measurements of $\mathrm{CF}_{2} \mathrm{Cl}_{2}$, which were performed from October 1980 to March 1983 at Memanbetsu, Hokkaido.

The trend of monthly mean volume mixing ratios of $\mathrm{CF}_{2} \mathrm{Cl}_{2}$, when the wind directions were between NW and $\mathrm{N}$, was considered to represent the trend of the background mixing ratios. In this case, the mean increase rate from October 1980 to March 1983 was $15 \mathrm{ppt} /$ year, which corresponded to the increase rate of $4.6 \% /$ year in January 1981 .

From the increase rate obtained in this study and the atmospheric release rate reported by CMA (1983), $\tau$ was calculated to be $24(5 \sim \infty)$ years. Such a short lifetime seems to be due to the overestimation of the release rate in 1980 and 1981 in comparison with the ALE data (Cunnold et al., 1983).

\section{References}

Ausloos, P., R. E. Rebbert, and L. Glasgow, 1977; Photodecomposition of chloromethanes adsorbed on silica surfaces, J. Res. Nat. Bur. Std., 82, $1-8$.

Chang, J. S., and J.E. Penner, 1978; Analysis of global budgets of halocarbons, Atmos. Environ., 12, 1867-1873.

Chemical Manufacturers Association (CMA), 1983; "Production, sales, and calculated release of CFC-11 and CFC-12 through 1982".

Cunnold, D., F. Alyea, and R. Prinn, 1978 ; A methodology for determining the atmospheric lifetime of fluorocarbons, J. Geophys. Res., 83, 5493-5500.

Cunnold, D. M., R. G. Prinn, R. A. Rasmussen, 
P. G. Simmonds, F. N. Alyea, C. A. Cardelino, and A. J. Crawford, 1983; The atmospheric lifetilme experiment 4 . Results for $\mathrm{CF}_{2} \mathrm{Cl}_{2}$ based on three years data, J. Geophys. Res., 88, 8401-8414.

Hirota, M., H. Muramatsu. Y. Makino, Y. Toyama, T. Sasaki, 1982; Measurements of minor constituents in the troposphere and the stratosphere by a gas-chromatographic method, Tech. Rep. Met. Res. Inst., No. 6, Chapter 1, p 5-41.

Makide, Y., Y. Kanai, and T. Tominaga, 1981; The ultratrace analysis of atmospheric halocarbons, J. Chem. Soc. Jpn., 133-144.

NAS, 1979; Stratospheric ozone depletion by halocarbons: Chemistry and transport, National Academy of Science, Washington, D.C.
Penkett, S. A., K. A. Brice, R. G. Derwent, and A. E. J. Eggleton, 1979; Measurement of $\mathrm{CCl}_{3} \mathrm{~F}$ and $\mathrm{CCl}_{4}$ at Harwell over the period January 1975-November 1977, Atmos. Environ., 13, 1011-1019.

Rasmussen, R. A., and M. A. K. Khalil, 1981; Differences in the concentrations of atmospheric trace gases in and above the tropical boundary layer, Pure Appl. Geophys., 119, 990-997.

Sze, N. D., and M. F. IVu, 1976; Measurements of fluorocarbons 11 and 12 and model validation: An assessment, Atmos. Environ., 10, 11171125.

Tominaga, T., and Y. Makide, 1983; Global distributions of atmospheric halocarbons (in Japanese), MAP news, No. 4; p7-9.

\section{北海道・女満別における大気中 $\mathrm{CF}_{2} \mathrm{CI}_{2}$ の測定 \\ —-1980年10月～1983年 3 月 \\ 広田道夫・村松久史・福井史雄* \\ 室松富二男*・橋本雅彦*・桑島正幸*・小池捷春*}

$\mathrm{CF}_{2} \mathrm{Cl}_{2}$ の大気中での寿命を求めるために, $\mathrm{CF}_{2} \mathrm{Cl}_{2}$ の測定を北海道・女满別に预いて 1980年10月から1983年 3 月まで行った。

風向がNWから $\mathrm{N}$ の場合の月平均体積混合比がバックグラウンドの変化傾向を表していると考えられたが，この 場合の年平均增加率は $1_{5} \mathrm{ppt} /$ 年 $\left(\mathrm{ppt}=10^{-12}\right)$ であった。

ここで得られた年増加率と大気放出率のデータ（CMA，1983）から大気中での寿命は24年（5年〜の）と計算 された。この值は従来推定されてきた值に比較して短かいが，これは1980年，1981年の放出量が多目に見積られて いるためであると考えられる。

*地磁気観測所女満別出張所 